\title{
Taiteen arkea ja juhlaa
}

\section{Pulneethivinorio}

Tutta Palin

Professoriluento Turun yliopistossa Maamme koko väkilukukaan ei tietysti 20.3.2019

Kun vastasin jokin aika sitten puolalaisen kollegan tiedusteluun taidehistorian professuurien lukumäärästä Suomessa, vastaukseni nauratti häntä eikä hän ilmeisesti täysin uskonut minua. Vakinaisia, ei-henkilökohtaisia alan professuureja on tällä hetkellä maamme tiedeyliopistoissa viisi, kun kuudes, Åbo Akademin vakanssi on parhaillaan täytössä tenure track -tehtävänä. Kollega ei varmaan tarkoittanut olla pilkallinen. Tiedossamme on, että Puolan tai Saksan kaltaisissa väkirikkaissa Manner-Euroopan maissa taidehistorian professoreja on jo yhdessä ja samassa yliopistossa yleensä vähintään kuusi siten, että he ovat erikoistuneita eri aikakausiin ja taidehistorian aloihin, perinteisimmän jaon mukaisesti eri kausien kuvataiteeseen tai arkkitehtuuriin. vastaa kuin yhtä keskieurooppalaista metropolia. Merkillepantavaa joka tapauksessa on, että Suomessa kokonaista taidehistorian kaltaista laajaa tieteenalaa on pitänyt täysimittaisena yllä varsin pieni joukko asialleen intohimoisesti omistautuneita ja määrätietoisia opettajia ja tutkijoita, jotka nykyään verkottuvat myös Euroopan ulkopuolelle. Useita heistä näen tänään ilokseni yleisössä.

Suomen kaltaisessa pienessä protestanttisessa maassa ei toki kuvien ja visuaalisen kulttuurin asema ole muutenkaan ollut yhtä itsestään selvä kuin katolisen tai ortodoksisen kulttuurin vaikutuspiirissä Euroopassa - jos nyt edelleen ajattelemme vain Eurooppaa. Kuviin on suhtauduttu jopa vihamielisesti tai ainakin välinpitämättömästi. Turun yliopistokin perustettiin kohta sata vuotta sitten nimenomaan suomenkieliseksi yliopistoksi, jonka alkuperäinen identiteetti perustui vah- vasti kieleen ja kirjallisuuteen (mitä vastaan en sinänsä propagoi, päinvastoin, kielen ja kirjallisuuden tutkimus on mitä tärkeintä).

Kuvataide joka tapauksessa miellettiin tässä historian vaiheessa helposti yläluokan ylellisyystuotteeksi. Yllättävää kyllä vielä nykyäänkin saattaa jopa akateemisissa yhteyksissä kuulla puhuttavan esimerkiksi orkideatieteestä. Tällaisiin luonnehdintoihin liittyy helposti sukupuolittavia mielikuvia siitä, mikä lasketaan todelliseksi työksi - siitä huolimatta että orkideojen kasvatus on tunnetusti vaativaa. Nykyään orkideoja on tosin Suomessakin saatavilla huokeasti lähimarketien hyllytavarana ja rautakaupan kampanjatuotteina, joten kielikuva ei ole aivan ajan tasalla.

Muutenkin visuaalisen informaation ja kuvanlukutaidon tärkeys kulttuurisessa vuorovaikutuksessa ja yhteiskunnallisten prosessien tulkinnassa on tullut monin tavoin ilmeisemmäksi. Visuaalisuus ei ole oma eril- 
linen elämänalueensa, vaikka taide nyky-yhteiskunnassa ehkä sitä onkin. Taidehistorian tieteenalalla ylläpidetään ja hiotaan tulkintataitoja, joiden tulisi kuulua jokaisen perusvalmiuksiin ja -oikeuksiin. IImitason lisäksi on tunnistettava myös piiloviestit ja kuvien tiedostamattomat ulottuvuudet: yhteydet kollektiivisiin tunnerakenteisiin ja kulttuurisiin lainalaisuuksiin mukaan lukien poliittiseen vaikuttamiseen liittyvät tarkoitusperät.

Taiteentutkimusta voi siis pitää laboratoriona, jossa kehitetään välineitä muuhunkin kuin kulttuurielämän tarpeisiin kulttuurielämää itsessään väheksymättä. Vaikka kulttuuriturismi ei maassamme ole yhtä merkittävä kansantuIon lähde kuin vaikkapa Ranskassa, taiteentutkijat osallistuvat monin tavoin yhteiskunnan rakentamiseen. Tämän hetken puheenaiheisiin kuuluvat esimerkiksi kulttuurin hyvinvointivaikutukset, joiden suhteen taiteen- ja kulttuurintutkijat tosin ovat useinkin itse kriittisimpiä - hyvinvointivaikutusten mittaaminen pitävästi on hankalaa, vaikka syy-yhteys voi tuntua todennäköiseltä tai itsestään selvältä. Helpointa on ehkä ajatella käänteisesti: minkälainen olisi kansakunta, jossa ei olisi lainkaan taide- ja kulttuurielämää ja jossa kulttuuriperintöä ei pidettäisi arvossa?
Myöskään kulttuuripalvelujen käyttäjien näkökulmaa ei tule väheksyä. Kulttuuriset mielihyvärakenteet ovat muuttuvia. Taidemuseoiden saavutettavuus on esimerkiksi museokortin myötä kasvanut, ja saamme jatkuvasti lukea uutisia korttelia kiertävistä jonoista taidemuseoihin, viimeksi uuteen Amos Rex -museoon Helsingissä. Amos Rexin tapauksessa kävijöitä ovat houkutelleet elämykselliset digitaaliset sovellukset ja vuorovaikutteiset immersiiviset tilat, mutta myös niin sanottu vanha taide vetää säännöllisesti suuria yleisöjä. Usein saa huomata, että itselle arkiseksi työksi muuttuneet tutkimuskohteet edustavat yleisölle juhlaa.

Museo- ja näyttelysektorilla työskentelevät kollegat kokevat työnsä kiitolliseksi ja palkitsevaksi suuren yleisön myönteisen ja innostuneen asenteen vuoksi. Itse olen koulutus- ja tutkimussektorin toimijana ja suomalaisen taiteen tutkijana niin ikään kokenut olevani luontevassa dialogissa taidehistorian ammattikentän ja ympäröivän yhteiskunnan kanssa, vaikka luottamus sivistysyliopiston ideaan tuntuukin viime vuosien poliittisissa suhdanteissa jossain määrin horjuneen talousmittarien noustua tuloksellisuuden arvioinnin keskiöön.
Suomessa on kaikkiaan 52 taidemuseota, ja niissä käy vuosittain lähes kolme miljoonaa kävijää. Taidemuseot ovat museoista kaikkein suosituimpia. Niiden osuus maan kaikista museoista on 17 prosenttia, mutta kävijöistä niiden kävijät muodostavat lähes puolet. Suomen museoissa on koulutettua museoammatillista henkilökuntaa yli tuhat henkeä. Taidemuseoiden museoammatillinen henkilökunta on pääosin taidehistoriaa pääaineena opiskelleita.

Viime vuosina taidemuseoalallakin on kasvavan kansainvälistymisen myötä alettu aiempaa selvemmin arvostaa myös tohtorin tutkintoa. Edellä mainitsemillani taidehistorian "rintamailla" tohtorin tutkinto on käytännössä melkeinpä edellytys vakinaisen asiantuntijatehtävän saamiselle, kun taas Suomessa on raskaampien tutkintojen perinne vasta taittumassa. Tohtorikoulutus vahvistaa siis sekä kansallisia että kansainvälisiä työllistymismahdollisuuksia vastaavaan tapaan kuin tutkimuksessa. Museoalan lisäksi taidehistoria valmistaa asiantuntijoita muihin näyttely- ja kulttuuriorganisaatioihin sekä kulttuurihallintoon ja kulttuuriperintöinstituutioihin. Myös nykytaiteen kenttä, jolla on sekä julkisen että yksityisen sektorin toimi- 
joita, työllistää alan ammattilaisia. Turussa taidehistorian opiskelijalla on materiaalisesti ja tilallisesti käsillä koko pohjoisen taidehistorian kaari vähintään keskiajalta nykykulttuuriin, ja yliopistomme arkeologit löytävät alueelta jatkuvasti lisää huomioitavaa.

Taidemuseoiden suosittuus on laajempi ilmiö, joka ei koske vain Suomea ja jota ei mahdollisesti voida lukea pelkästään taidehistorioitsijoiden ansioksi. Osittain tähän vaikuttavat uudet sähköisen viestinnän muodot ja yleisöjen tavoittamisen tavat. Mukana on paljon some-käyttäytymistä kuten selfieiden ottaminen kuuluisien taideteosten äärellä. Alan kokemuksellinen kenttä laajenee näin jatkuvasti edellyttäen vastaavasti laajenevaa tieteidenvälistä mutta myös sektorien välistä yhteistyötä, jolla onkin taidehistoriassa lujat perinteet.

Korostettakoon kuitenkin, että tällä hetkellä tendenssinä olevan laajojen yleisöjen tavoittelemisen lisäksi kulissien takana on tehtävä pitkäjänteistä kulttuuriperintötyötä ja kehitettävä edelleen välineitä kulttuurin ja yhteiskunnan kriittiseen itsereflektointiin. Taidehistorian tarkastelemilla visuaalisilla, tilallisilla ja materiaalisilla prosesseilla on tässä oma tärkeä osuutensa.
Tekijänoikeuksista neuvottelevana tahona museosektori on reagoinut proaktiivisemmin digitalisaatioon ja aineistojen avaamiseen, kun taas verkkojulkaisemista koskevan tekijänoikeuslainsäädännön viivästyminen hankaloittaa vielä tälläkin hetkellä tieteellistä open access -julkaisemista eli avointa tiedettä. Taiteentutkimuksessa työskennellään paljolti tekijänoikeudellisesti suojatun aineiston parissa, eikä aina nykypäiviin saakka tiedettä ja opetusta Suomessa edistänyt sitaattioikeus koske samassa määrin avointa sähköistä julkaisemista.

Näyttelyjulkaisut, kansainvälisessä käytännössä keskeinen taidehistoriallisen tutkimuksen foorumi, joka tavoittaa samanaikaisesti niin akateemiset ja museo- ja taidekentän asiantuntijat kuin suuremman yleisön, ovat muuttuneet tieteellisen julkaisemisen kompastuskiveksi - näin siitäkin huolimatta, että näyttelyjulkaisujen yhteydessä perinteenä ovat useat erikieliset laitokset. Vaikka kokoelmaluettelot ja catalogue raisonnét (taiteilijakohtaiset tieteelliset teosluettelot) voivat jo olla sähköisiä ja näyttelyopasteet ovat muuttuneet omaan älypuhelimeen ladattaviksi sovelluksiksi, näyttelyluettelot tuskin muuttuvat koskaan kokonaan digitaalisiksi. Taidehistorioitsijat tulevat edelleen tarvitsemaan hyllytilaa poikkeuksellisen painaville ja suurikokoisille kuvitetuille kirjoilleen niin yliopiston kirjastossa kuin työpisteissään. Uusia, tieteen arviointimalleihin sopivia, vertaisarviointikäytäntöä noudattavia julkaisufoorumeita on museosektorillakin nyt kuitenkin kehitteillä.

\section{$\star \star \star$}

Kun itse opiskelin taidehistoriaa 1980-luvulla, nykytaiteen tutkimus teki vasta tuloaan tieteenalalle, ja käytiin tänään hyvin oudolta vaikuttavaa keskustelua siitä, että historiassa voitaisiin tutkia vain niin sanottuja päättyneitä prosesseja. Tämä liittyi silloiseen ajatukseen, jonka mukaan taidehistorioitsijan tuli kyetä arvottamaan - ennen muuta esteettisesti - tarkastelemiaan ilmiöitä. Sittemmin on totuttu ajattelemaan, että menneisyys ja nykypäivä eivät erotu näin olemuksellisesti toisistaan ja näkemään taidehistoria kriittisen kulttuurintutkimuksen alana. Historia ei itse asiassa edes tarkoita menneisyyttä, vaan muiden aikojen monikerroksista läsnäoloa omassa kokemuksessamme, siis tässä hetkessä. 
Nykyilmiöt ovat sittemmin juurtuneet elimelliseksi osaksi tieteenalaa, jonka nimenä suomenkielisessä Suomessa on edelleen taidehistoria - historiallisista syistä ja mahdollisesti siksi, että germaanisissa kielissä käytössä oleva ilmaisu taidetiede kuulostaisi suomeksi eri kieliperimän vuoksi sattumoisin kömpelöltä ja epäluontevalta. Nykytaiteen laajentuneella kentällä taide voi tarkoittaa myös vaikkapa äänitaidetta, jolla itse asiassa on yhteytensä tilan hahmottamiseen ja visuaalisiinkin mielikuviin. Historiallinen muuttuvuus liittyy läheisesti tieteenalan avainkäsitteeseen, taiteeseen.

Tieteenalan nimi kertoo sen synnystä osana 1800-luvun historiatieteitä, myös Suomessa. Taiteen käsitteellä taas on tarkoitettu joustavasti hyvin erilaisia visuaalisia, tilallisia ja materiaalisia ilmiöitä, joiden toisilleen läheisiksi kokemisen taustalla ovat usein koulutusinstituutiot, jopa konkreettinen fyysinen läheisyys. Taideakatemioissa, joiden opetusohjelma perustui paljolti piirtämiseen, opetettiin vanhastaan sekä kuvataidetta että arkkitehtuuria. Suomessa taiteen rinnalle, joskin omaksi osastokseen, sijoitettiin mielenkiintoista kyllä jo 1800-luvun lopulla myös taideteollisuusala. Tämä kertoo taiteen lähtökohtaisesta arkisuudesta mannereurooppalaisittain perifeerisessä mutta modernisaatioon innostuneesti suuntautuneessa yhteiskunnassa. Se on myös tarkoittanut vahvaa taiteentutkimuksen kytköstä moderniteetin kokemukseen ja moderneihin käytäntöihin, joiden myötä monet korkeakulttuurin ilmiöt ovat arkipäiväistyneet ja jalkautuneet ainakin keskiluokan ellei koko kansan pariin. Taiteen juhlasta on tullut taiteen arkea.

Omasta tutkimuksestani tämä on tuttua esimerkiksi muotokuvan lajityypistä, joka on teknisten innovaatioiden myötä muuttunut alun perin aristokraattisesta vallan manifestaatiosta äärimmäisen muuntautumiskykyiseksi, aina uusia välineitä ja mediumeja hyödyntäväksi arkisen itseilmaisun muodoksi. Monta kertaa kuolleeksi julistettu ilmiö on nykyään kaikkialla läsnä arjessamme.

Korkean ja matalan, arjen ja juhlan, jatkuva toisiinsa lomittuminen samoin kuin taiteen käsitteen notkea muuntautumiskyky ja tieteenalan kyky sisällyttää itseensä aina uusia ilmiöitä on itselleni arvokkainta taidehistorian perintöä, jota toivon voivani omalta osaltani ylläpitää. Korostettakoon, että uusia ilmiöitä ovat myös muuttuvat historian tulkinnat osana nykypäivää.
Aloitin puheenvuoroni maamme taidehistorian professorien määrää laskemalla. $\mathrm{Pa}$ laan nyt asiaan luennon loppua enteilevästi.

Vaikka taidehistorian oppituolit sijoittuvat Turun yliopistossa, Åbo Akademilla, Helsingin yliopistossa ja Jyväskylän yliopistossa varsin erilaisiin intellektuaalisiin miljöihin ja tieteenalakokonaisuuksiin, jolloin jo luonnostaan tapahtuu profiloitumista, alalla on vahva kansainvälisiin ja valtakunnallisiin yhteyksiin perustuva identiteetti. Turun yliopistossa moderni ja nykytaide sekä saman ajan visuaalinen kulttuuri laajemmin ymmärrettynä ovat selvä painopistealue. Tutkimuksen profiloituessa on kuitenkin tärkeää pitää samalla silmällä laaja-alaisuutta voidaksemme reagoida joustavasti työmarkkinoiden muutoksiin ja kansainväliseen kehitykseen ja tarjota edelleen peruskoulutusta, joka on kilpailukykyinen suhteessa muiden maiden koulutustarjontaan. Tämä on mahdollista erilaisia vuorovaikutus- ja yhteistyöverkostoja edelleen kehittämällä.

Tutta Palin nimitettiin Turun yliopiston taidehistorian professoriksi 1.1.2019 alkaen. 